\title{
Oral literature in South Africa: 20 years on
}

\author{
Duncan Brown
}

\begin{abstract}
I offer a retrospective on the field of orality and performance studies in South Africa from the perspective of 2016, assessing what has been achieved, what may have happened inadvertently or worryingly, what some of the significant implications have been, what remain challenges, and how we may think of, or rethink, orality and performance studies in a present and future that are changing at almost inconceivable pace.
\end{abstract}

This article was initially delivered as a keynote address at the conference, "Orature in South Africa: An Arc to the Future", which was coupled with a joint project of the same name, headed by Andrew van der Vlies of Queen Mary College, University of London, and Deborah Seddon of Rhodes University, to produce a digital archive of historical and contemporary orality and performance from South Africa. The context is important, as I sought to offer a retrospective on the field of orality and performance studies in South Africa from the perspective, then, of 2016, assessing what has been achieved, what may have happened inadvertently or worryingly, what some of the significant implications have been, what remain challenges, and how we may think of, or rethink, orality and performance studies in a present and future that are changing at almost inconceivable pace.

Orality and performance, of course, have been with us as far back as we can trace in human histories, and to adapt J M Coetzee's famous metaphor of narrative being a cockroach which survives no matter what (1988: 2-5), orality and performance will no doubt outlive us all, though likely in forms that we cannot yet even begin to comprehend. Orality studies, however, in the sense of academic studies (rather than, for example, discussions amongst performers themselves about technique and evaluation) have a far more recent history, and a somewhat less clear future, though I am by no means pessimistic about that.

Much of the pioneering work on oral literature in southern Africa occurred within the context of colonisation: whether by missionaries seeking to understand their prospective converts and their languages more adequately; magistrates or governors wanting to find 'better' ways to govern; state ethnographers or linguists in the service and advocacy of empire (often with explicitly Social-Darwinist agendas); or an admixture of the above coupled with apparently genuine interest. The legacy, in work of people like James Stuart, AT Bryant, Henry Callaway or Wilhelm Bleek and Lucy Lloyd, is an invaluable archive of material and scholarship, though one requiring careful contextualisation. There have also been significant and ground-breaking studies of oral literature by black scholars, in particular H I E 
Dhlomo (1993 [1939], 1977 [1947-1948]), B W Vilakazi (1993 [1938], 1945), A C Jordan (1973), D P Kunene (1971), and Mazisi Kunene (1961), which continue to inform orality studies today. With the 'retribalising' policy of the National Party following its coming to power in South Africa in 1948, studies of oral literature

- especially in departments of African languages - became, in some cases, problematically entangled with the ideology of apartheid and its promotion of fossilised and essentialised notions of 'ethnic identity' and 'racial otherness'; or they restricted themselves to the 'safe' areas of lexical study or morphology over the more challenging and resistant potential of oral texts in South Africa. Nevertheless, crucial studies appeared by M Damane and P B Sanders (1974), Aaron C Hodza and George Fortune (1979), Trevor Cope (1968), Isaac Schapera (1965), and D Rycroft and A B Ngcobo (1988) studies which deserve renewed attention from scholars today.

Along with the studies mentioned above, Ruth Finnegan's wide-ranging Oral Poetry: Its Nature, Significance and Context (1977), Jeff Opland's pioneering study, Xhosa Oral Poetry: Aspects of a Black South African Tradition (1983), and Liz Gunner's mammoth two-volume doctoral thesis, "Ukubonga Nezibongo: Zulu Praising and Praises" (1984) were foundational in establishing the field of oral-literature study in South Africa.

As is evident in reading much of this pioneering work, until fairly recently studies of oral literature worldwide tended in approach to be either anthropological/historical or literaryformalist (I include on both sides of this distinction scholars working in the hoarily defined area of 'folklore'). With some notable exceptions (in relation to southern Africa, particularly the work of David B Coplan 1994, Deborah James 1999, Veit Erlmann 1996, and Jean Comaroff and John Comaroff 1991), anthropological and historical studies have emphasised the role of the text as a carrier of cultural or social information and paid little attention to literary form. Literary studies, in turn, have tended to remove forms from the time, place, and circumstances out of which they have emerged. The ideas of Milman Parry (1971), who in the 1920 s and 1930 s studied the Homeric tradition and its parallels with modern Slavic epics, and those of his student Albert Lord, have dominated discussions of orality in departments of literature (1960). Both Parry and Lord treat oral literature as a universal genre characterised by common techniques of composition and delivery rather than as emerging in distinct forms in disparate historical circumstances. Certainly Parry's emphasis on the performer's ability to improvise directed much-needed attention to the individual-aesthetic shaping of material in contrast to the anthropological reading which located the poem or story in the 'collective consciousness' or 'memory' of the 'tribe' or 'band'. Parry is unable to account, however, for the functioning of oral texts within specific societies. Instead, as Ruth Finnegan argued, criticism of the Parry-Lord school tends to confine itself to the "study of detailed stylistic points and formulaic systems leading to statistical conclusions" (1976: 127).

In 1989 a rather scruffy-looking, cardboard-bound book appeared. It emerged out of a oneday seminar run by the Centre of West African Studies at the University of Birmingham. I 
am referring, of course, to Karin Barber and P F de Moraes Farias's edited collection, Discourse and Its Disguises: The Interpretation of African Oral Texts (1989). It appeared at the same time as Bill Ashcroft, Gareth Griffiths, and Helen Tiffin's much vaunted The Empire Writes Back: Theory and Practice in Post-colonial Literatures (1989), and was in its own way as influential on its field of study as The Empire Writes Back was on postcolonial studies. The seminar focused on the apparent impasse between the somewhat decontextualised formalism of literary scholars and the approach of anthropologists/historians for whom oral texts were simply sources of social or historical information. "What seemed to be required", they argued, "was an approach that acknowledged simultaneously the historicity and textuality of oral texts, that combined a sociology with a poetics of oral literature" (1989: 1). For them, "[t]he issue was how to put textuality into history, and history back into textuality" (2). It was an approach which I found engaging and productive, and which informed my work at the time, as well as that of scholars in literary studies, anthropology, and ethnomusicology.

Why a retrospective look at orality and performance studies twenty years on? I will argue that there was a key set of publications clustering loosely around the median point of 1995, admittedly often with somewhat divergent imperatives and methodologies, which established the field of a more theorised study of orality in South Africa, working at the nexus of textuality and historicity, whether explicitly informed by Barber and de Moraes Farias's argument or not. Leroy Vail and Landeg White's Power and the Praise Poem: Southern African Voices in History (1991), Isabel Hofmeyr's "We Spend our Years as a Tale That Is Told": Oral Historical Narrative in an African Chiefdom (1993), and Karin Barber's "I Could Speak until Tomorrow": Oriki, Women and the Past in a Yoruba Town (1991) are three landmark studies which are still frequently referenced today. Barber's study, of course, focuses on material from Nigeria, not South Africa, but its exploration of the kinds of approaches outlined in Discourse and Its Disguises in an extended study of bodies of oral performance was extremely suggestive for scholars in South Africa and elsewhere, including my own work in Voicing the Text: South African Oral Poetry and Performance (1998), and the edited collection, Oral Literature and Performance in Southern Africa (1999). Russell H Kaschula's edited volume, Foundations in Southern African Oral Literature (1993), collected and reprinted seminal papers and articles on the study of oral literature from the first half of the twentieth century alongside a few slightly later pieces. It was invaluable in giving contemporary researchers a sense of the history of scholarship on which they could build. Liz Gunner and Mafika Gwala's anthology, Musho: Zulu Popular Praises (published in the US in 1991 but in 1994 in South Africa), with a significant 52-page critical introduction, dispatched the notion that the only Zulu praises worthy of critical attention were those of significant male leaders. Megan Biesele's Women Like Meat: The Folklore and Foraging Ideology of the Kalahari Ju/'hoan (1993) was bold enough to introduce the concepts of ideology, economics, and gender relations into the arena of Khoisan studies, previously demarcated as the terrain of myth and folklore. Stewart Brown's edited volume of chapters on orality in Africa and the diaspora, The Pressures of the Text: Orality, Texts and the Telling of Tales (1995), took the significant work of Discourse and Its Disguises to broader geographical and intellectual terrains. Liz Gunner's edited volume, Politics and Performance: Theatre, Poetry and Song in Southern 
Africa (1994), offered comparative studies across South Africa, Zimbabwe, and Zambia, whilst the volume she co-edited with Graham Furniss, Power, Marginality and African Oral Literature (1995), placed studies of South African orality and performance in conversation with performances and critical work across the African continent. Harold Scheub's collection, The Tongue Is Fire: South African Storytellers and Apartheid (1996), reproduces an extraordinary range of Swati, Xhosa, Ndebele, and Zulu narratives between the Sharpeville massacre and the Soweto uprising, narratives which are powerful and compelling. Jeff Opland's Xhosa Poets and Poetry (1998) - a follow-up to his 1983 study - takes his work into challenging new realms, amongst others the complex interplay between performance and print in newspapers and mission presses. The ethnomusicologist Carol Ann Muller combined intense fieldwork with highly theorised analysis in her account of women's performance genres in the Church of the Nazarites in the monograph Rituals of Fertility and the Sacrifice of Desire: Nazarite Women's Performance in South Africa (1999). In her study Songs of the Women Migrants: Performance and Identity in South Africa (1999), the anthropologist Deborah James examined the performance and mediation of migrant women's identities through song genres like kiba and others. David B Coplan explored textualities of identity, migrancy, and travel in his study In the Time of Cannibals: The Word Music of South Africa's Basotho Migrants (1994). And although it does not quite fit in with my 'twenty years on' argument, I must include Russell H Kaschula's The Bones of the Ancestors Are Shaking: Xhosa Oral Poetry in Context (2002), which is valuable both for its critical insights and its publication of poems from the nineteenth century through to praises for Mandela after his release from prison, Joe Slovo, and even the national football team Bafana Bafana. ${ }^{1}$

I need to add a caveat here. It would be inaccurate to assume that the work of Barber, de Moraes Farias and the other authors influenced by their thinking occasioned a radical break from older models in the field of orality and performance studies. Aspects of formalism (especially the Parry-Lord model) and the folkloric are still evident in even the most recent publications of some scholars, Jeff Opland or Harold Scheub being notable examples.

These studies, along with those which preceded them, had profound effects which should not be underestimated. Chief amongst these were the legitimising of the study of the oral and performative, including developing the paradigms and methodologies to do so; undermining Social-Darwinist understandings of the relations between orality and literacy, fundamental to colonial thinking, but having a surprisingly and stubbornly insistent afterlife; demonstrating and insisting upon the aesthetic and intellectual validity of performance genres and the individuals and societies involved; recovering voices or providing entry for them into the academy; and broadening the scope and possibilities of literary study, anthropology, ethnomusicology, oral history, and more broadly, study in the humanities.

A crucial contribution made by such studies is also that they stand as a corrective to the English language, elite genre, print focus of much work in postcolonial studies, which I would like to explore a little further. It should be noted, though, that the potential of this 
corrective has not been fully realised, as orality and postcolonial studies have not adequately engaged each other.

The lack of engagement by postcolonial scholars in South Africa (and elsewhere) with the oral and the performative may be attributable in part to a wariness of the relative lack of historicisation or theorisation in the institutional practices of oral studies in the past, as well as to larger resistances to the oral within literary studies itself, but I think certain difficulties within postcolonial studies are also causative. In particular, the potentially homogenising effect of the postcolonial studies model, as well as problems within its conception of agency and silence on the part of the colonised, needs further scrutiny.

In its overarching theorisation of coloniser-colonised and centre-margin relations, postcolonial studies often construct a homogenising grand narrative which is insufficiently cognisant of the particularities of local histories, and which tends to elide specific voice, or erase any distinctiveness of identity or action, even tilting, on occasion, "towards a description of all kinds of oppression and discursive control", as Stephen Slemon notes (1994: 22). In her eloquent, if polemical, article "African-Language Literature and Postcolonial Criticism”, Karin Barber makes the point forcefully:

The 'postcolonial' criticism of the 1980 os and 1990 - which both continues and inverts the 'Common-wealth' criticism inaugurated in the 1960s - has promoted a binarised, generalised model of the world which has had the effect of eliminating African-language expression from view. This model has produced an impoverished and distorted picture of the colonial experience' and the place of language in that experience. It has maintained a centre-periphery polarity which both exaggerates and simplifies the effects of the colonial imposition of European languages. It turns the colonising countries into unchanging monoliths, and the colonised into a homogenised token: "that most tedious, generic hold-all, 'the postcolonial Other", as McClintock puts it - an Other whose experience is determined so overwhelmingly by his or her relation to the metropolitan centre that class, gender and other local historical and social pressures are elided. Despite intermittent claims to specificity, this model blocks a properly historical, localised understanding of any scene of colonial and post-Independence literary production in Africa. (1999: 125)

This grand narrative she continues, quoting Robert C Young, is centrally concerned with empire's inscription of itself, and pays only the most glancing attention to colonised peoples themselves, despite apparently being impelled by their needs:

In so far as it is invoked at all, the indigenous discourse appears only fleetingly, glimpsed out of the corner of the eye, conjured up almost inadvertently; it crosses the path of colonial criticism obliquely, metaphorically, ambivalently and evasively, only to advertise its own inaccessibility. The theoretical effect is to consign 'native' discourses to the realms of the unknowable, or to imply that they were displaced, erased or absorbed by the dominant colonial discourses. (1999: 128-9) 
The effect of this kind of argument is to problematise the notion of agency for the colonised: "what actually happened", Barber reminds us, "was not only, or always, the result of colonial policies" (1999: 141) - a position supported by Benita Parry (1994), amongst others. A proper engagement with orality and performance studies, such as these listed above, makes this kind of position (even if Barber is caricaturing somewhat) utterly untenable.

There are, however, challenges which I think we need to address in the study of oral literature or orature. In her review of Megan Biesele's book Women Like Meat, Isabel Hofmeyr expressed a slight concern at its "sweeping and deterministic mode-of-production argument" (1999: 23), in which the texts are analysed and validated in terms of their social functionality. It is a trend evident in much of the work of the time, including my own, as we sought as scholars to argue for the importance and legitimacy of such material. ${ }^{2}$ It is evident in the titles, subtitles, or section titles of many of the studies referred to above, in which the oral texts are analysed in relation to political power, the mediation of identity, the expression of agency and opposition, and so on. Here are some examples: "Power and the Praise Poem"; "The Folkore and Foraging Ideology of the Kalahari Ju/'hoan"; "Power, Marginality and Oral Literature"; "Orality and the Power of the State"; "Representing Power Relations"; or "Mediators and Communicative Strategies". I am not arguing that this was wrong at the time, but am concerned about the lingering effects of that approach. Even at the height of the 'theory wars' when, as I have argued in an article recently, the 'literary' as 'literary' was something of an embarrassment to critics, I do not think that the novel, play, or lyric poem were ever held to such strict socio-political account. In that article, I argued that:

I find myself thinking towards a literary scholarship which is more comfortable with the unpredictability, contrariness and unruliness of the literary; which is not embarrassed by the affective, nor feels the need to bracket it off or explain its 'functionality'; which deploys theory as it is useful, rather than being disciplined by it or - worse - using 'theory' to discipline 'literature'; a scholarship which is less monumental and institutionally proclaimed; which is instead more nimble, and also more humble; which is less sure about its own grounds of working and its aims, but is clear that there is a great deal at stake - the very notions of what it means to be human, humane, civil, compassionate. It is a mode of reading, thinking living - which is potentially more attuned to the vicious, beautiful, transnational, parochial, hopeful, hopelessly betrayed place which is postapartheid South Africa. (2014: 1123)

I would want something of that approach to permeate the study of orality and performance genres.

Another concern in considering orality and performance studies 'twenty years on', and which is no doubt symptomatic of the 'nation building' agenda of the mid-1990s in the wake of the first democratic election, is that some studies were overtly or tacitly (unconsciously?) informed by a nationalist agenda, especially in the case of literary scholars seeking to create more inclusive literary histories (and I include myself here). At its worst, the national model understands orality as something localised and of the past. Indeed, despite the best efforts of a 
range of scholars to argue otherwise, for many literary scholars and especially literary historians, orality remains only an originary presence. It tends to be adduced as a gesture towards precolonial societies, and then end-stopped around the time of the establishment of the mission presses. When I saw the title of this conference and project, in which orature was "an arc into the future", I was delighted. Despite abundant evidence that orality and performance are alive and well, they remain for some critics, something which can be referenced and mercifully forgotten. This tendency can be illustrated by the recent The Cambridge History of South African Literature, edited by David Attwell and Derek Attridge. In their Introduction they say of the field of South African literature:

Several literary traditions, oral and written, have fed into the complex array of verbal productions charted in this volume, at times influencing or infiltrating one another, and at other times ignoring or challenging one another. From indigenous folk-tales to European elite art, these traditions have been constantly reworked and reinvented, creating an extensive body of literary art that continues to grow, despite the smallness of the home market and very limited financial means of most potential readers. (2012: 1)

The phrase "from indigenous folk-tales to European elite art" may or may not involve a set of developmental assumptions, but more worrying is the fact that their study follows the by now fairly conventional positioning of the oral and performative as a point of origin and historical record, and which implies a conception of the literary and aesthetic which is insufficiently responsive to the possibilities and insurrections of the oral-performative in a world of explosive technological opportunity and social rearrangement. Michael Chapman argues correctly in this regard that:

The character of the southern African region ensures that the category of the oral retains both a living and interpretative significance. As in many configurations of the South of the world, the traditional, the modern and the postmodern exist audibly and visibly in simultaneous and antagonistic relationship to the life of the present day. (2016:1)

In talking about the continued presence and significance of the oral and performative, I do not just mean rap and hip hop, which are genres with long histories. The single widely regarded as the first rap song released commercially, "Rapper's Delight" by the Sugarhill Gang, appeared 36 years ago in 1979, around 21 years before many of our students were born; and a song like "Lose Yourself" by Eminem, a rap standard by any measure, is already 13 years old, released before some of our students entered Grade One.

Whilst there are certainly performance genres which remain locally specific, in terms of performers, audience, and genre, orality and performance have in many cases become decidedly transnational in reference and reach. Orality in the present - as a range of unruly global genres which insist on being heard, but also resist critical containment - demands a somewhat different response. 
For me some of the most interesting critical work on orality and performance recently in South Africa has been conducted by scholars who approach the field equipped with the theoretical skills and abilities which come from a grounding in mainstream literary studies, especially literary theory. I would divide them into two, possibly distinct but certainly overlapping categories. There are scholars like Nkosinathi Sithole (2005, 2010) and Mbongiseni Buthelezi (2004, 2012), who are extremely proficient in the languages of the work which they are researching, and so can combine the traditional fieldwork approach of collecting materials and interviewing performers with sophisticated understandings of processes of transcription and translation, a nuanced sense of the ambiguities and contradictions of their own positions (both are insiders and outsiders in the societies with which they engage), and an ability to deploy theory in analysis. Then there are scholars like Michael Wessels and Ashlee Neser, who work with texts in English translation only, but use theory to interrogate conceptual terms and modes of analysis which are frequently uncritically deployed in oral studies, so producing new, challenging readings of materials previously read rather differently.

Let me elaborate. Nkosinathi Sithole is a member of the Church of the Nazarites. He has an undergraduate degree in African literature and an Honours in English. For his masters and doctoral theses, the latter about to appear as a monograph, he conducted research, respectively, on near-death narratives and hymn performance and dance in the Church. He was theoretically adept enough to negotiate his position as both church member and scholar, and actually make this a significant advantage in his work (no easy feat, as the Church itself is very hierarchical). The Church of the Nazarites has been the subject of a great deal of scholarship, but in almost all cases conducted by white researchers from outside the Church. Sithole's work brought to light a great deal of material which had not yet been published, provided greater insight into the Church than had been possible previously, and also corrected some of the theoretical misconceptions and analyses of previous studies.

Mbongiseni Buthelezi came to his postgraduate work with an undergraduate degree in Drama and Performance and English, and an English Honours degree. His masters and doctoral work involved uncovering an alternative history to the 'official' Zulu, Buthelezi and Ndwandwe narratives. This was accomplished through an analysis of official izibongo, whether already transcribed or recorded by himself, as well as 'less official' praises and narratives. Not only did he have to engage in a similar insider/outsider negotiation to Sithole, but his personal safety was of grave concern in the overheated identity politics of KwaZulu-Natal. His ability as a literary scholar with excellent skills in isiZulu allowed him to read against the grain of texts, and pick out contradictions and dissonances, to deconstruct their rhetorics of power, and also to read sensitively for the ways in which other possible narratives were being constructed. The result is some of the most incisive and insightful analysis to have appeared in the field for some time.

To move to scholars working on texts in English translation, when I first heard that Michael Wessels was proposing a Foucauldian reading of the /Xam Bushman material in the Bleek 
and Lloyd archives, I have to be honest that I thought this might be an example of theory gone mad. But his work has convinced me otherwise. His book Bushman Letters: Interpreting /Xam Narrative (2010), which is based on his doctoral thesis, is to me a ground-breaking study. Wessels uses literary theory, chiefly but not only Foucault, to examine the genealogy of some of the terms, conceptual categories, or critical assumptions - 'trickster' is one he explores at some length - which have assumed currency in oral studies and anthropology and which have directed interpretations (including my own) without scholars and readers challenging the values, behaviours, and epistemologies which may be implied by the term, and what their origins might be (in Jung and Radin, amongst others, in the case of the trickster). Once these founding concepts and categories are opened for reappraisal, new, more self-reflexive readings become possible, and the archive begins to unfold rather differently.

Like Wessels, in her book Stranger at Home: The Praise Poet in Apartheid South Africa (2011), which is also based on her doctoral thesis, Ashlee Neser - using insights derived from literary theory - seeks to offer new readings of material which has been extensively covered, in this case in the scholarship of Jeff Opland.

Opland's work with and on the Xhosa imbongi David Yali-Manisi is extremely well known, and Opland has himself written an autobiographical account of his personal and professional relationship with Manisi in The Dassie and the Hunter: A South African Meeting (2005). Opland recorded Manisi performing on public occasions before leaders at significant gatherings, in one-on-one meetings with him, and in lecture tours which they undertook together, in which Opland would explain the form of izibongo, and Manisi would then perform a poem.

To take one crucial aspect of Neser's argument, she engages with a fundamental and consistent distinction which Opland makes in his analysis of Manisi's work. He distinguishes between 'performances' which take place before, say, a Xhosa leader and assembly, and 'demonstrations' which might be for a group of students or academics, following a lecture in which Opland explained the genre of izibongo. Behind Opland's distinction appear to lie assumptions about 'real' or 'authentic' aesthetic events and engagements, and those 'displaying' a technique or skill. Using amongst other things performance theory Neser, for her part, argues that the poems which Manisi did for students in a lecture theatre are as much 'performances' as those before a Xhosa leader, and that Manisi was skilful enough a poet to be able to negotiate his performances across a range of audiences and expectations. Such an understanding expands one's grasp of his performative ability and the capacity of the genre, rather than reducing him to a talented demonstrator; it also opens up those performances for more complex readings, which is welcome and appropriate: in front of students and academics, whether South African or American, Manisi took no prisoners.

A last significant area for studies of oral literature and performance for me, and one which will be immeasurably enabled by the digitisation of material through the "Arc to the Future" project, is a serious engagement with some of the major figures as intellectuals in their own 
right, and who in many cases considered themselves as such. Many of these thinkers were working at the interface between orality and literacy, and this becomes a point at which orality can engage usefully with scholarship on the history of the book, for example that of Andrew van der Vlies (2007) or Isabel Hofmeyr (2004, 2013). The publication of works such as the following offers significant possibilities for this kind of research: The Nation's Bounty: The Xhosa Poetry of Nontsizi Mgqwetho (2007), edited and translated by Jeff Opland; S E K Mqhayi's Abantu Besizwe: Historical and Biographical Writings, 1902-1944 (2009), also edited and translated by Opland; William Wellington Gqoba's Isizwe Esinembali: Xhosa Histories and Poetry (1873-1888) (2015), edited and translated by Opland, Wandile Kuse, and Pamela Maseko; and D L P Yali-Manisi's Iimbali Zama-nyange: Historical Poems (2015), edited and translated by Opland and Pamela Maseko. When we engage with such works, our sense of our intellectual history becomes enormously richer and more complex, and issues which we may think are current or of our time prove in many cases to have been anticipated and thoroughly discussed many decades earlier.

I want to conclude on a personal note, but hope that it points up broader, more significant issues. I was recently up for re-rating by the National Research Foundation (NRF), and my application was successful, but it came back with comments to this end: firstly, that "the candidate should be wary of conducting research in too many different areas"; and, secondly, that the "field of orality and performance studies had not perhaps proved to be the major new field of study which it had promised to be". Many of us have issues with the NRF rating system, so I was not overly concerned by these comments, but they do suggest some troubling assumptions. The first comment seems to assume the science model of research, in which if you research sea sponges, that is what you do in perpetuity. That does not translate to the Humanities, and especially to literary and cultural studies. I see moving from one area of study to another related one as broadening one's thinking, and where new areas of study are opened up or existing ones rethought, redefined, or deepened, broadening the collective field of, in my case, literary and cultural studies.

The second comment is even more troubling. Perhaps others might have felt differently, but I never conducted research on oral literature and performance with the aim of establishing, or further establishing, it as a separate field of study. In contrast, I was explicit about locating my work within the context of literary studies (though librarians have consistently frustrated my attempts by cataloguing my work in anthropology). My rationale was that if we were to write literary histories which reflected what had actually happened in this country, or many others like it, or to understand the range of what had been produced historically and in the present, we needed more sophisticated ways of engaging with orality and performance.

In this lies the value of the conference to which I referred at the outset, especially in the larger digitisation project behind it, which will make material available to scholars in all branches of study, not just to those working in a narrowly defined field such as orality and performance studies. 


\section{Notes on Contributor}

Duncan Brown is Professor of English and Dean of the Faculty of Arts at the University of the Western Cape, a fellow of the Stellenbosch Institute for Advanced Study, and a fellow of the University of KwaZulu-Natal. His publications include Voicing the Text: South African Oral Poetry and Performance and Are Trout South African? Stories of Fish, People and Places.

\section{Disclosure statement}

No potential conflict of interest was reported by the author.

\section{Notes}

1. By far the majority of these publications are from Wits University Press, and we should acknowledge the significant role of this publisher in establishing and promoting this field of study.

2. In my later work on rap I specifically tried to account for the genre's 'pleasure' and 'play' alongside its real engagement with social, political, and economic issues (Brown 2006: 15386). 


\section{References}

Ashcroft, Bill, Gareth Griffiths and Helen Tiffin. 1989. The Empire Writes Back: Theory and Practice in Post-colonial Literatures. London and New York: Routledge.

Attwell, David and Derek Attridge (eds). 2012. The Cambridge History of South African Literature. Cambridge: Cambridge University Press.

Barber, Karin. 1991. "I Could Speak until Tomorrow": Oriki, Women and the Past in a Yoruba Town. Edinburgh: Edinburgh University Press.

Barber, Karin. 1999. “African-Language Literature and Postcolonial Criticism.” In: T J Cribb (ed.). Imagined

Commonwealths: Cambridge Essays on Commonwealth and International Literature in English. London: Macmillan: 125-65.

Barber, Karin and P F de Moraes Farias (eds). 1989. Discourse and Its Disguises: The Interpretation of African Oral Texts. Birmingham University African Studies Series 1. Birmingham: Centre of West African Studies.

Biesele, Megan. 1993. Women Like Meat: The Folklore and Foraging Ideology of the Kalahari Ju'/hoan.

Bloomington and Indianapolis: Indiana University Press; Johannesburg: Wits University Press.

Brown, Stewart (ed.). 1995. The Pressures of the Text: Orality, Texts and the Telling of Tales. Birmingham

University African Studies Series 4. Birmingham: Centre of West African Studies, University of Birmingham.

Brown, Duncan. 1998. Voicing the Text: South African Oral Poetry and Performance. Cape Town: Oxford University Press.

Brown, Duncan (ed.). 1999. Oral Literature and Performance in Southern Africa. Oxford: James Currey; Cape Town: David Philip/Athens: Ohio University Press.

Brown, Duncan. 2006. To Speak of This Land: Identity and Belonging in South Africa and Beyond. Pietermaritzburg: University of KwaZulu-Natal Press.

Brown, Duncan. 2014. "Reimagining South African Literature." Journal of Southern African Studies 40 (5): 1109-23.

Buthelezi, Mbongiseni. 2004. "Kof' abantu, kosal' izibongo: Contested Histories of Shaka, Phungashe and Zwide in Izibongo and Izithakazelo." MAThesis. Durban: University of KwaZulu-Natal.

Buthelezi, Mbongiseni. 2012. "Sifuna umlando wethu (We are Looking for our History): Oral Literature and the Meanings of the Past in Post-Apartheid South Africa." PhD Thesis. New York: Columbia University.

Chapman, Michael. 2016. "Oral' in Literary History: The Case of Southern African Literatures." In: Daniel F Chamberlain and J Edward Chamberlin (eds). Or Words to That Effect: Orality and the Writing of Literary History, 149-161. Amsterdam: John Benjamins.

Coetzee, J M. 1988. “The Novel Today.” UpStream 6 (1): 2-5.

Comaroff, Jean and John L Comaroff. 1991. Of Revelation and Revolution: Christianity, Colonialism and 
Consciousness in South Africa: Volume One. Chicago and London: University of Chicago Press.

Cope, Trevor (ed.). 1968. Izibongo: Zulu Praise-Poems. Oxford: Clarendon Press.

Coplan, David B. 1994. In the Time of Cannibals: The Word Music of South Africa's Basotho Migrants. Chicago and London: University of Chicago Press.

Damane, M and P B Sanders (eds). 1974. Lithoko: Sotho Praise Poems. Oxford: Clarendon Press.

Dhlomo, H I E.1977 [1947-1948]. "Zulu Folk Poetry." English in Africa 4 (2): 43-59.

Dhlomo, H I E.1993 [1939]. "Nature and Variety of Tribal Drama." In: Russell H Kaschula (ed.). Foundations in Southern African Oral Literature. Johannesburg: Wits University Press: 187-202.

Erlmann, Veit. 1996. Nightsong: Performance, Power, and Practice in South Africa. Chicago and London: University of Chicago Press.

Finnegan, Ruth. 1976. "What is Oral Literature Anyway?" In: B A Stoltz and R S Shanna (eds). Oral Literature and the Formula. Ann Arbor, Michigan: Centre for the Coordination of Ancient and Modern Studies: 123-54.

Finnegan, Ruth. 1977. Oral Poetry: Its Nature, Significance and Context. Cambridge: Cambridge University Press.

Furniss, Graham and Liz Gunner (eds). 1995. Power, Marginality and African Oral Literature. Johannesburg: Wits University Press; Cambridge: Cambridge University Press.

Gqoba,WilliamWellington. 2015. Isizwe Esinembali - Xhosa Histories and Poetry (18731888). Edited and translated by Jeff Opland,Wandile Kuse and Pamela Maseko. Pietermaritzburg: University of KwaZulu-Natal Press.

Gunner, Liz. 1984. "Ukubonga Nezibongo: Zulu Praising and Praises.” DPhil Thesis. London: SOAS: University of London.

Gunner, Liz. (ed.). 1994. Politics and Performance: Theatre Poetry and Song in Southern Africa. Johannesburg: Wits University Press.

Hodza, Aaron C. and George Fortune (eds). 1979. Shona Praise Poetry. Oxford: Clarendon Press.

Hofmeyr, Isabel. 1993. "We Spend Our Years as a Tale that is Told": Oral Historical Narrative in a South African Chiefdom. Johannesburg: Wits University Press; Portsmouth, NH: Heinemann; London: James Currey.

Hofmeyr, Isabel. 1999. "Making Symmetrical Knowledge Possible: Recent Trends in the Field of Southern African Oral Performance Studies.” In: Duncan Brown (ed.). Oral Literature and Performance in Southern Africa. Oxford: James Currey/Cape Town: David Philip/Athens: Ohio University Press: 18-26.

Hofmeyr, Isabel. 2004. The Portable Bunyan: A Transnational History of The Pilgrim's Progress. Princeton and Oxford: Princeton University Press.

Hofmeyr, Isabel. 2013. Ghandi's Printing Press: Experiments in Slow Reading. Cambridge, MA: Harvard University Press.

James, Deborah. 1999. Songs of the Women Migrants: Performance and Identity in South Africa. Edinburgh: Edinburgh University Press. 
Jordan, A C. 1973. Towards an African Literature: The Emergence of Literary Form in Xhosa. Berkeley: University of California Press.

Kaschula, Russell H. (ed.). 1993. Foundations in Southern African Oral Literature. Johannesburg: Wits University Press.

Kaschula, Russell H. 2002. The Bones of the Ancestors are Shaking: Xhosa Oral Poetry in Context. Cape Town: Juta.

Kunene, Mazisi. 1961. "An Analytical Survey of Zulu Poetry both Traditional and Modern." MA Thesis. Durban: University of Natal.

Kunene, D P. 1971. Heroic Poetry of the Basotho. Oxford: Clarendon Press.

Lord, Albert B. 1960. The Singer of Tales. Cambridge, MA: Harvard University Press.

Mqhayi, S E K. 2009. Abantu Besizwe: Historical and Biographical Writings, 1902-1944. Edited and translated by Jeff Opland. Johannesburg: Wits University Press.

Muller, Carol Ann. 1999. Rituals of Fertility and the Sacrifice of Desire: Nazarite Women's Performance in South Africa. Chicago and London: University of Chicago Press.

Neser, Ashlee. 2011. Stranger at Home: The Praise Poet in Apartheid South Africa. Johannesburg: Wits University Press.

Opland, Jeff. 1983

Opland, Jeff. 1998. Xhosa Poets and Poetry. Cape Town: David Philip.

Opland, Jeff. 2005. The Dassie and the Hunter: A South African Meeting. Pietermaritzburg: University of KwaZulu-Natal Press.

Opland, Jeff (ed. and transl.). 2007. The Nation's Bounty: The Xhosa Poetry of Nontsizi Mgqwetho. Johannesburg: Wits University Press.

Parry, Benita. 1994. "Resisting Theory/Theorising Resistance, or Two Cheers for Nativism." In: Francis Barker, Peter Hulme and Margaret Iversen (eds). Colonial Discourse/Postcolonial Theory. Manchester and New York: Manchester University Press: $172-96$.

Parry, Milman. 1971. The Making of Homeric Verse: The Collected Papers of Milman Parry. Edited by Adam Parry. Oxford: Clarendon Press.

Rycroft, D. and A B Ngcobo. 1988. The Praises of Dingana: Izibongo zikaDingana. Pietermaritzburg: University of Natal Press.

Schapera, Isaac (ed.). 1965. The Praise Poems of the Tswana. Oxford: Clarendon Press.

Scheub, Harold. 1996. The Tongue is Fire: South African Storytellers and Apartheid. Madison: University of Wisconsin Press.

Sithole, Nkosinathi. 2005. "Testimony, Identity and Power: Oral Narratives of Near-Death Experiences in the Church of the Nazarites.” MAThesis. Pietermaritzburg: University of KwaZulu-Natal.

Sithole, Nkosinathi. 2010. "Performance, Power and Agency: Isaiah Shembe's Hymns and the Sacred Dance in the Church of the Nazarites." PhD Thesis. Pietermaritzburg: University of KwaZulu-Natal.

Slemon, Stephen. 1994. "The Scramble for Post-colonialism." In: Chris Tiffin and Alan Lawson (eds). De-Scribing Empire: Post-colonialism and Textuality. London and New York: Routledge: $15-32$.

Vail, Leroy and Landeg White. 1991. Power and the Praise Poem. Charlottesville: University Press of Virginia/London: James Currey. 
Van der Vlies, Andrew. 2007. South African Textual Cultures: White, Black, Read all Over. Manchester and New York: Manchester University Press.

Vilakazi, B W. 1945. "The Oral and Written Literature in Nguni." D.Litt. Dissertation. Johannesburg: University of the Witwatersrand.

Vilakazi, B W. 1993 [1938]. “The Conception and Development of Poetry in Zulu.” In: Russell H Kaschula (ed.). Foundations in Southern African Oral Literature. Johannesburg: Wits University Press: 55-84.

Wessels, Michael. 2010. Bushman Letters: Interpreting /Xam Narrative. Johannesburg: Wits University Press.

Yali-Manisi, D L P. 2015. Iimbali Zamanyange: Historical Poems. Edited and translated by Jeff Opland and Pamela Maseko. Pietermaritzburg: University of KwaZulu-Natal Press. 